\title{
Laparoscopy or laparotomy for high-risk caesarean scar pregnancy: a retrospective study
}

\author{
Ronghua Liu ${ }^{1}$, Pengfei Cui ${ }^{1}$, wenwen wang ${ }^{1}$, Ting Zhou ${ }^{1}$, and SHIXUAN WANG ${ }^{1}$ \\ ${ }^{1}$ Affiliation not available
}

June 12,2020

\begin{abstract}
Objective The aim of this study was to compare the outcomes of laparotomy and laparoscopy in the treatment of highrisk caesarean scar pregnancy (CSP) and evaluate the optimal treatment measure. Design A retrospective study. Setting Tongji Hospital. Population Two hundred seventy-eight patients with CSP between 2013 and 2018. Methods We compared and analysed the characteristics of laparoscopic and open surgery in the treatment of high-risk CSP and the advantages and disadvantages of different methods of vascular pretreatment. We also systematically evaluated CSP patients undergoing laparoscopic or laparotomic surgery. Results The intraoperative bleeding volume, transfusion rate, and total number of days of hospitalization and postoperative hospitalization were better in the laparoscopy group than in the laparotomy group $(\mathrm{p}<0.05)$. There were no differences in factors ( $\beta$-hCG decrease, reoperation and residual tissue) closely related to surgical success between the two groups. Furthermore, we pretreated blood vessels differently before the operation. The residual tissue, reoperation and intraoperative blood transfusion rates in patients treated with temporary vascular occlusion were better than those in patients treated with permanent vascular occlusion. A systematic review of English literature showed that most of the current studies on CSP are case reports and retrospective analyses ( $67.74 \%$ and $29.03 \%$, respectively), and the sample sizes of these studies are very small. Conclusions This study reveals that laparoscopic surgery is superior to laparotomic surgery in the treatment of high-risk CSP. Patients benefitted from temporary arterial occlusion in both groups. Temporary arterial occlusion with laparoscopic surgery may be the best treatment for high-risk CSP.
\end{abstract}

\section{Hosted file}

manuscript .doc available at https : //authorea.com/users/327614/articles/459134-laparoscopy-orlaparotomy-for-high-risk-caesarean-scar-pregnancy-a-retrospective-study

\section{Hosted file}

Table 1.docx available at https://authorea.com/users/327614/articles/459134-laparoscopy-orlaparotomy-for-high-risk-caesarean-scar-pregnancy-a-retrospective-study

\section{Hosted file}

Table 2.docx available at https://authorea.com/users/327614/articles/459134-laparoscopy-orlaparotomy-for-high-risk-caesarean-scar-pregnancy-a-retrospective-study

\section{Hosted file}

Table 3.docx available at https://authorea.com/users/327614/articles/459134-laparoscopy-orlaparotomy-for-high-risk-caesarean-scar-pregnancy-a-retrospective-study

\section{Hosted file}


Table 4.docx available at https://authorea.com/users/327614/articles/459134-laparoscopy-orlaparotomy-for-high-risk-caesarean-scar-pregnancy-a-retrospective-study

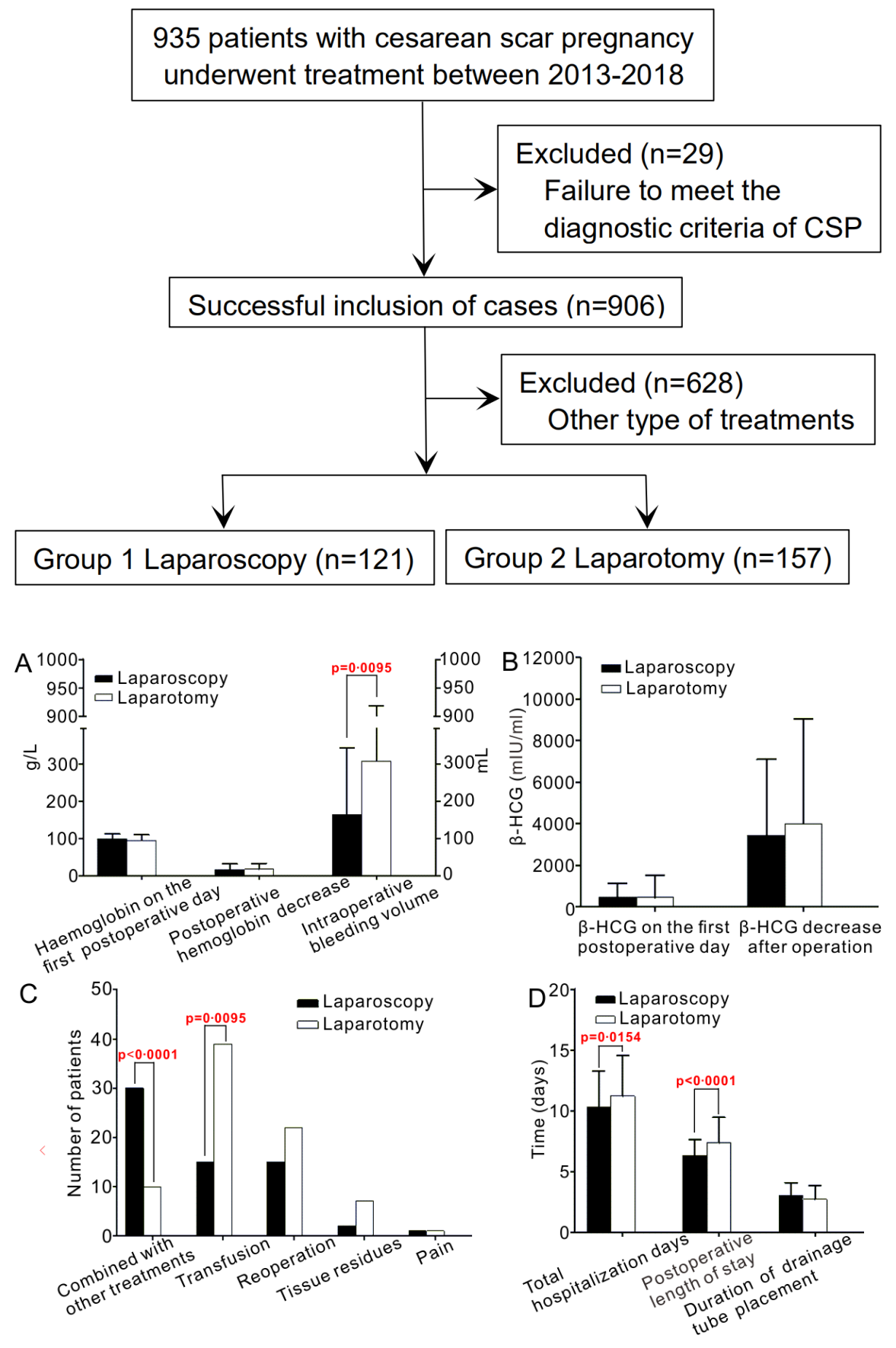




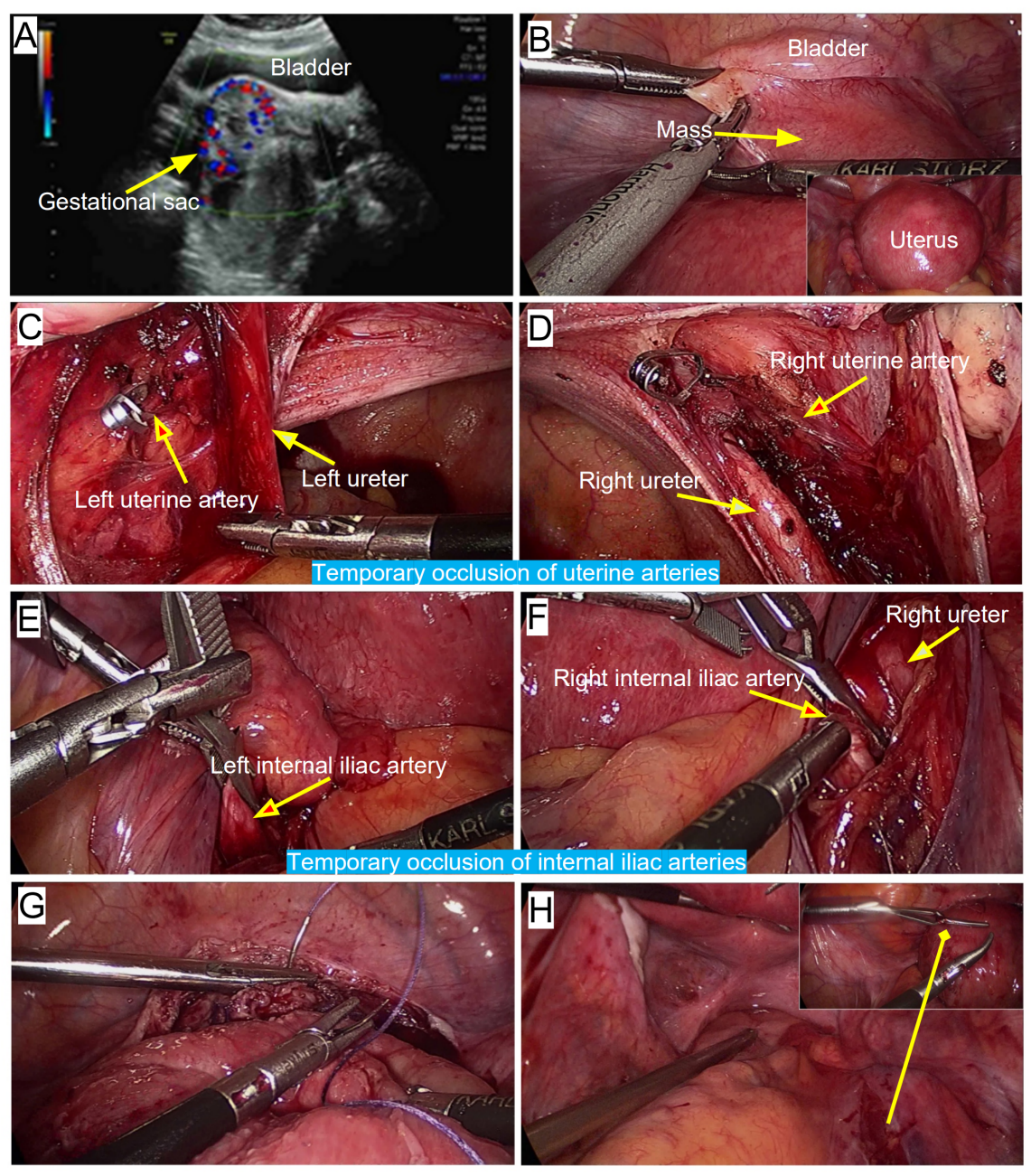

